\title{
Food intake by the parrotfish Scarus ferrugineus varies seasonally and is determined by temperature, size and territoriality
}

\author{
Y. Afeworki ${ }^{1,2, *}$, Z. A. Zekeria ${ }^{2}$, J. J. Videler ${ }^{1}$, J. H. Bruggemann ${ }^{3}$ \\ ${ }^{1}$ Department of Ocean Ecosystems, University of Groningen, PO Box 14, 9750 AA Haren, The Netherlands \\ ${ }^{2}$ Department of Applied Marine Science, College of Marine Science and Technology, PO Box 170, Massawa, Eritrea \\ ${ }^{3}$ Laboratoire d'Ecologie Marine (ECOMAR) - FRE CNRS 3560, Université de la Réunion, CS 92003, 97744 Saint Denis, \\ La Réunion, France
}

\begin{abstract}
On coral reefs, feeding by parrotfishes may prevent coral to macroalgal phase shifts by keeping algae in a cropped state. To predict the response of grazers to changing conditions, knowledge of the factors that affect feeding intensity is needed. Therefore, we studied food intake of the parrotfish Scarus ferrugineus on an inshore fringing reef in the southern Red Sea, Eritrea, where seasonality and extreme summer temperatures were expected to influence feeding rates. Bite rates (bites $\mathrm{min}^{-1}$ ), defecation rates (defecations $\mathrm{min}^{-1}$ ) and yield per bite (mass ingested bite $^{-1}$ ) were estimated for 3 life-phase categories: 20 to $25 \mathrm{~cm}$ initial phase (IP), 30 to $35 \mathrm{~cm}$ terminal phase (TP) and 30 to $35 \mathrm{~cm}$ territorial terminal phase (TTP). The bite rates increased from low levels in the morning to peak values in the afternoon. IP bite rates increased linearly with seawater temperature. For TP, the temperature-bite rate relationship was quadratic, with maximum bite rates at $\sim 32^{\circ} \mathrm{C}$ and lower rates at higher temperatures. Yield per bite in both IP and TP did not differ with time of year. Throughout the year, the total daily bites were highest in IP and lowest in TTP, resulting in $\sim 23 \%$ lower daily intake in TTP compared to similar-sized TP males. Daily intake of ash-free dry mass of epilithic algal matrix ( $\left(\mathrm{g} \mathrm{AFDM} \mathrm{d}{ }^{-1}\right.$ ) was 7.5 to 9.6 for IP, 12.4 to 17.5 for TP and 8.7 to 13.2 for TTP. Intake and defecation rates and hence gut turnover rates peaked from April to July. The quadratic temperature response of TP suggests that large individuals may be close to their upper thermal limit, implying that temperature rises are likely to negatively affect grazing by large-bodied parrotfishes.
\end{abstract}

KEY WORDS: Coral reefs $\cdot$ Herbivory $\cdot$ Grazing rate $\cdot$ Extreme environments $\cdot$ Southern Red Sea · Resilience

\section{INTRODUCTION}

Marine herbivorous fishes achieve the highest densities and diversity in tropical coral reef ecosystems (Floeter et al. 2005). Grazing rates on coral reefs are known to be extremely high; grazers are capable of removing 50 to $90 \%$ of the daily production of turf algae (Hatcher 1982, Klumpp \& Polunin 1990, van Rooij et al. 1998). The primary grazing target is the epilithic algal matrix (EAM), composed of algal turfs with associated biota and detritus (Wilson et al. 2003). Despite its low standing crop, the EAM is known to support high grazer biomass because of high productivity (Carpenter 1985, Klumpp \& Mckinnon 1989).

Parrotfishes often represent a large proportion of the total grazer biomass (van Rooij et al. 1998, Williams \& Polunin 2001). Most parrotfishes feed by 
scraping or excavating the EAM from the dead coral matrix (Bellwood \& Choat 1990, Bruggemann et al. 1994c). This feeding action is a major structuring force of coral reef benthic communities, controlling the biomass and distribution of benthic algae, enhancing coral recruitment and generally promoting reef recovery (Mumby et al. 2007). Despite their low-quality diet, parrotfishes show fast growth rates (Russ \& St. John 1988, van Rooij et al. 1995b). Compared to other similar-sized fishes such as acanthurids, parrotfishes generally have shorter life spans (Choat \& Robertson 2002) and suffer higher predation rates (Sudekum et al. 1991, Kingsford 1992). These traits indicate a high population turnover and suggest that parrotfish populations may play an important role in energy transfer in coral reef ecosystems.

Behavioural aspects of parrotfish foraging such as patterns in habitat use, preference for substrates and bite rates have been studied extensively (Bruggemann et al. 1994a, Afeworki et al. 2011, 2013). Bite rates in parrotfish vary as a function of innate factors such as body size, social status and feeding mode (excavator vs. scraper) (Bruggemann et al. 1994b,c, Bonaldo et al. 2006) and environmental factors such as temperature, nutritional quality and productivity (Carpenter 1988, Targett \& Targett 1990, Ferreira et al. 1998, Smith 2008).

Temperature is perhaps the most critical determinant of intake rate in ectotherms. The hump-shaped relationship between temperature and food intake indicates limits to intake rate at both low and high temperatures (Horn \& Gibson 1990, Koskela et al. 1997, Englund et al. 2011). The emphasis of past research on coral reefs has been on limits to grazing at low temperatures (Horn 1989, Floeter et al. 2005, Smith 2008). It is not known whether rising temperatures will promote or suppress grazing in coral reefs. Individual grazing rates could increase because of rises in temperature (Smith 2008). Conversely, higher temperatures may lead to communities dominated by smaller-bodied individuals (Munday et al. 2008, Barneche et al. 2009, Daufresne et al. 2009), which may reduce grazer impact and coral reef resilience.

Coral reefs in extreme environments such as the Arabian Gulf and southern Red Sea provide useful settings to explore how rising temperatures may impact coral reefs in the future (Feary et al. 2010). Inshore reefs of the southern Red Sea are characterized by extreme summer temperatures $\left(>33^{\circ} \mathrm{C}\right.$ at $2 \mathrm{~m}$ depth) that are higher than in most coral reef areas (Ateweberhan et al. 2005b). Moreover, regional sea surface temperatures have shown a rapid increase of $0.7^{\circ} \mathrm{C}$ since the mid-1990s (Raitsos et al. 2011). Tem- peratures as high as $36^{\circ} \mathrm{C}$ on shallow reef flats have been implicated as a cause for lower grazing rates in this zone during summer (Ateweberhan et al. 2006, Afeworki et al. 2013). Despite a relatively narrow annual temperature range $\left(<10^{\circ} \mathrm{C}\right)$, the area experiences significant seasonal changes in the productivity and community composition of benthic algae (Ateweberhan et al. 2006), and in fish growth (Zekeria et al. 2006). Moreover, the area experiences recurrent bleaching of corals during summer (Y. Afeworki \& J. H. Bruggemann pers. obs.). This is mainly because the summer temperatures are extremely high, causing many of the benthic communities to persist close to their upper critical temperatures (Ateweberhan et al. 2005b, 2006). In this study, we make use of this seasonality to investigate the effects of extreme summer temperatures on bite rates and food intake by different social categories of Scarus ferrugineus on an inshore fringing reef in the southern Red Sea.

\section{MATERIALS AND METHODS}

\section{Study site and species}

The study was conducted on the shallow fringing reefs of Sheikh Said Island $\left(15^{\circ} 35^{\prime} \mathrm{N}, 39^{\circ} 29^{\prime} \mathrm{E}\right)$ in the southern Red Sea, Eritrea, between 2005 and 2007. For a detailed description of the study site, see Ateweberhan et al. (2006) and Afeworki et al. (2011). Mean monthly sea surface temperature (SST) at $2 \mathrm{~m}$ depth ranges from $27.7^{\circ} \mathrm{C}$ in January to $33.4^{\circ} \mathrm{C}$ in August (Ateweberhan et al. 2006). This monsoondriven seasonality in SST is associated with significant changes in the composition, cover and biomass of benthic algae (Ateweberhan et al. 2006). Turf algae, the primary food source of Scarus ferrugineus, achieve their highest cover during the hot season (Ateweberhan et al. 2006, Afeworki et al. 2011), while foliose and canopy-forming macroalgae dominate the shallow reef zones during the cool season (Ateweberhan et al. 2006).

Scarus ferrugineus is the dominant grazer on the reefs of the southern Red Sea and constitutes about $34 \%$ of the total biomass of herbivorous fishes (Afeworki et al. 2013). This species forages primarily on the reef crest and shallow fore-reef zones (Afeworki et al. 2011). Like most other labrids, S. ferrugineus is a protogynous hermaphrodite with 2 distinct life phases: the drab initial female phase (IP) and the colourful terminal male phase (TP). A subset of the TP keep temporary spawning territories outside 
the main foraging zones and are considered a third category, territorial terminal phase (TTP). IP reach $26 \mathrm{~cm}$ in length, and TP reach $36 \mathrm{~cm}$. Three size and social categories are the main focus of this study: 20 to $25 \mathrm{~cm}$ IP (henceforth IP), 30 to $35 \mathrm{~cm}$ TP (henceforth TP) and 30 to $35 \mathrm{~cm}$ territorial TP (henceforth TTP).

\section{Bite and defecation rates}

Haphazardly selected individuals of Scarus ferrugineus were allowed to acclimatize to the presence of the observer for $3 \mathrm{~min}$. The fork length, life phase, time of day and date were recorded. Selected individuals were observed for 5 to $15 \mathrm{~min}$ and the number of bites and defecations recorded, either directly in the field or from underwater videos recorded by following a focal fish with a handheld camera (Sony digital camera model DSC-W17). Bite and defecation rates were calculated as number of bites (defecations) per minute. All observations were made by snorkelling or SCUBA. Because of the absence of spear fishing or fish feeding by divers, observations at close range $(<0.5 \mathrm{~m}$ distance) are possible with no discernible change in the behaviour of the focal fish. Underwater size estimation was practiced with PVC pipes of known length or by estimating fish size before spearing them. Size of videoed individuals was estimated from frames with objects of known dimensions as a scale.

Bite rates were sampled in 2 mo periods (henceforth period), by combining months with similar SST (see Supplement 1 at www.int-res.com/articles/ suppl/m489p213_supp.pdf for details). Observations were conducted in all but the December-January period. Periods are nested within the 2 distinctive southern Red Sea cool (December to March) and hot (May to October) seasons (Ateweberhan et al. 2006). Dawn-to-dusk observations of feeding were made on focal IP and TP fish, while observations of feeding of TTP were conducted during spawning episodes. To determine the beginning and the end of the feeding day, several dives were conducted around sunrise and sunset to record the first and last bites for most periods except the April-May period, where the values of August-September, a period with similar day lengths, were taken. Complete dawn-to-dusk records of defecations were made during the February-March and October-November periods only. During the other periods (except April-May), defecation rates were recorded between 11:00 and 18:00 h.

\section{Bite rates, total daily bites and daily intake rates}

Bite rate was plotted against time (minutes after midnight) and a polynomial quadratic function fitted to the data from IP, TP and TTP fish. A second-order polynomial was selected because it fitted the data best; it has been successfully used to explain feeding patterns in scarids (Bellwood 1995, Ong \& Holland 2010). The cumulative number of total daily bites (TDB) is the area under this curve delimited by the beginning and end of the feeding day. TDB was determined for each month and life phase category. Daily intake rate was estimated as the product of TDB and yield per bite.

\section{Yield per bite}

The amount of food ingested per bite was estimated using a modification of the gut-fullness method (Montgomery 1980, Polunin 1988). IP and TP fish were speared throughout the morning hours between the start of feeding and first defecation in February-March and October-November. Plots of defecation rates against time of day were used to identify the time when defecation commences (see Fig. 5). The mass of empty guts was determined from a different group of fish that were captured using a barrier net and kept overnight in situ in perforated barrels to allow them to evacuate their gut contents. Collected (speared) fish were kept chilled and were transported to the lab for dissection. The entire gut, from the oesophagus posterior of the pharyngeal mill to the anus, was excised. Dry mass (DM) (after drying at $60^{\circ} \mathrm{C}$ for $24 \mathrm{~h}$ ) and ash-free dry mass (AFDM, after burning in a muffle furnace at $550^{\circ} \mathrm{C}$ for $8 \mathrm{~h}$ ) of the gut plus contents were determined to the nearest $0.01 \mathrm{~g}$. The cumulative number of bites a fish had taken prior to being speared was estimated from the area under the bite rate curves (see Fig. 4) delimited by the start of feeding until the time the fish was speared. The slope of the regression line of gut mass (DM or AFDM) against number of bites gives the yield in grams of DM or AFDM per bite.

\section{Statistical analysis}

Mean bite rates recorded by direct field observation and by video were not significantly different (ANOVA: $F_{1,283}=1.16, \mathrm{p}=0.28$ ); hence, these data were pooled for further analysis. ANCOVA was used 


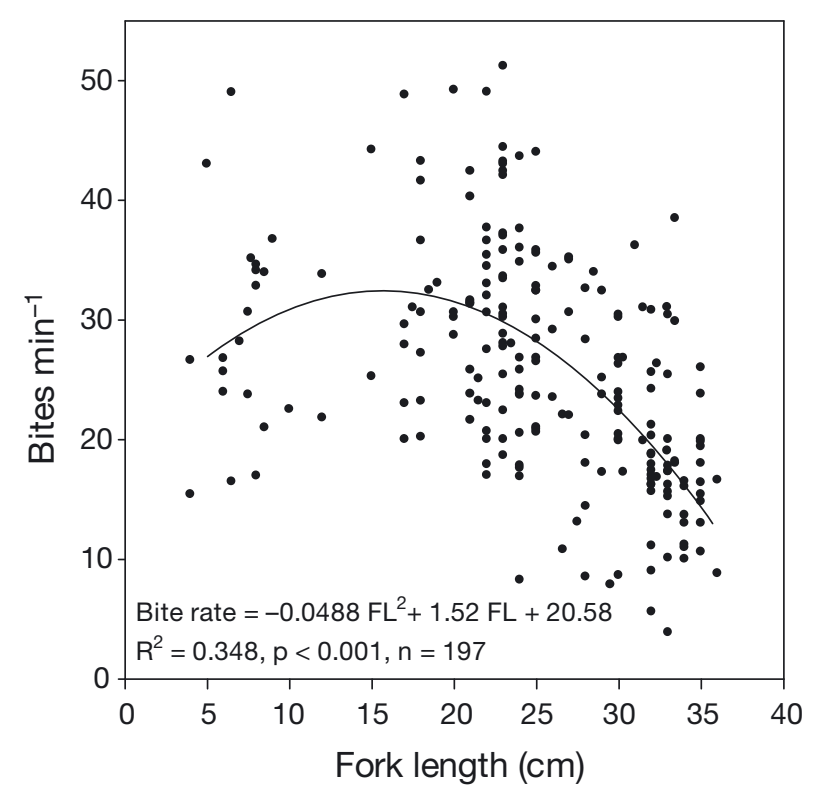

Fig. 1. Scarus ferrugineus. Relationship between fork length (FL) and bite rate in the southern Red Sea during JuneJuly and August-September

to test differences in bite rate among life phases, taking life phase as a fixed factor and fork length as a covariate. Comparison of bite rates between TP and TTP was conducted by ANOVA. Relationships between monthly mean SST and monthly mean bite rate were established using regression models in SPSS, and the best-fitting curve was selected based on $\mathrm{R}^{2}$ values.

Every day between 06:00 and 13:00 h, TTP were engaged in either of 2 activities (states): foraging in the shallow reef zones or defending a spawning territory at the deep fore-reef. Spawning activity lasted approximately $3 \mathrm{~h}$, i.e. about $50 \%$ of the morning, with the exact timing depending on tidal state (Y. Afeworki unpubl. data). In this case, a reasonable approach to estimate the mean bite rate for the morning hours is to give equal chance for observations taken during spawning and non-spawning periods. Therefore, TTP bite rates before 13:00 h were analysed by randomly taking equal numbers of observations from both states. Between 13:00 h and dusk, all TTP bite rate data were recorded during nonspawning episodes.

To compare differences in yield per bite between the 2 periods, ANCOVA was conducted by taking gut DM as a dependent variable, cumulative number of bites as a covariate, and period and life phase as factors. When no difference was detected between periods, linear regression was conducted on the pooled data to estimate the slope, i.e. the yield per bite.
Linear combinations of dependent parameters were used to estimate variances and confidence intervals of TDB. Differences in TDB between months and the 3 life phase categories were compared using the $Z$-test in combination with the false discovery rate procedure to correct for multiplicity (Benjamini \& Hochberg 1995). The overall error term for the daily intake rate was estimated by adding the relative uncertainties in TDB and yield per bite (propagation of error). Prior to conducting parametric tests, assumptions of normality and equality of variances were verified using Kolmogorov-Smirnov and Levene tests, respectively, in the Explore procedure of SPSS for Windows v. 16 (2007).

\section{RESULTS}

\section{Bite rates}

Bite rate was significantly different between the 2 size classes and among periods (ANCOVA; size: $F_{1,379}=210.151, \mathrm{p}<0.001 ;$ period: $F_{4,379}=7.63, \mathrm{p}<$ $0.001)$. There was no interaction between period and fish size, suggesting that size differences in bite rate are similar throughout the year. Bite rate was higher in the smaller size class (IP) than in the larger one (TP). Tests conducted on a separate data set (see Supplement 3) indicate that similar-sized IP and TP fish have equal bite rates, suggesting that the observed difference is the effect of body size, not life phase. Analysis of a larger dataset, including fish sizes outside the focal groups discussed here (see Supplement 3), demonstrated that fish size and bite rate are related by a quadratic function (Fig. 1), with peak values around 15 to $20 \mathrm{~cm}$.

During spawning episodes, the bite rate of TTP was significantly lower than the bite rates of similar-sized TP (Fig. 2). Bite rates were highest during April-May and lowest during February-March. Monthly mean SST had a significant effect on the bite rate of Scarus ferrugineus. For IP fish, bite rate increased linearly with SST $\left(\mathrm{R}^{2}=0.496, F_{2,5}=5.907, \mathrm{p}=0.051, \mathrm{n}=8\right.$, Fig. 3), while for TP fish the bite rate declined when mean SST exceeded $32^{\circ} \mathrm{C}$, such that a second-order polynomial best described the relationship between SST and bite rate for this life phase $\left(\mathrm{R}^{2}=0.905, F_{2,5}=\right.$ 23.863, $\mathrm{p}=0.003, \mathrm{n}=8$, Fig. 3).

For all life phases, bite rate increased steadily during the morning and reached peak values between 15:00 and 16:00 h. This daily trend was strongest during the warmer months (Fig. 4). During the cooler February-March period, this daily rhythm 

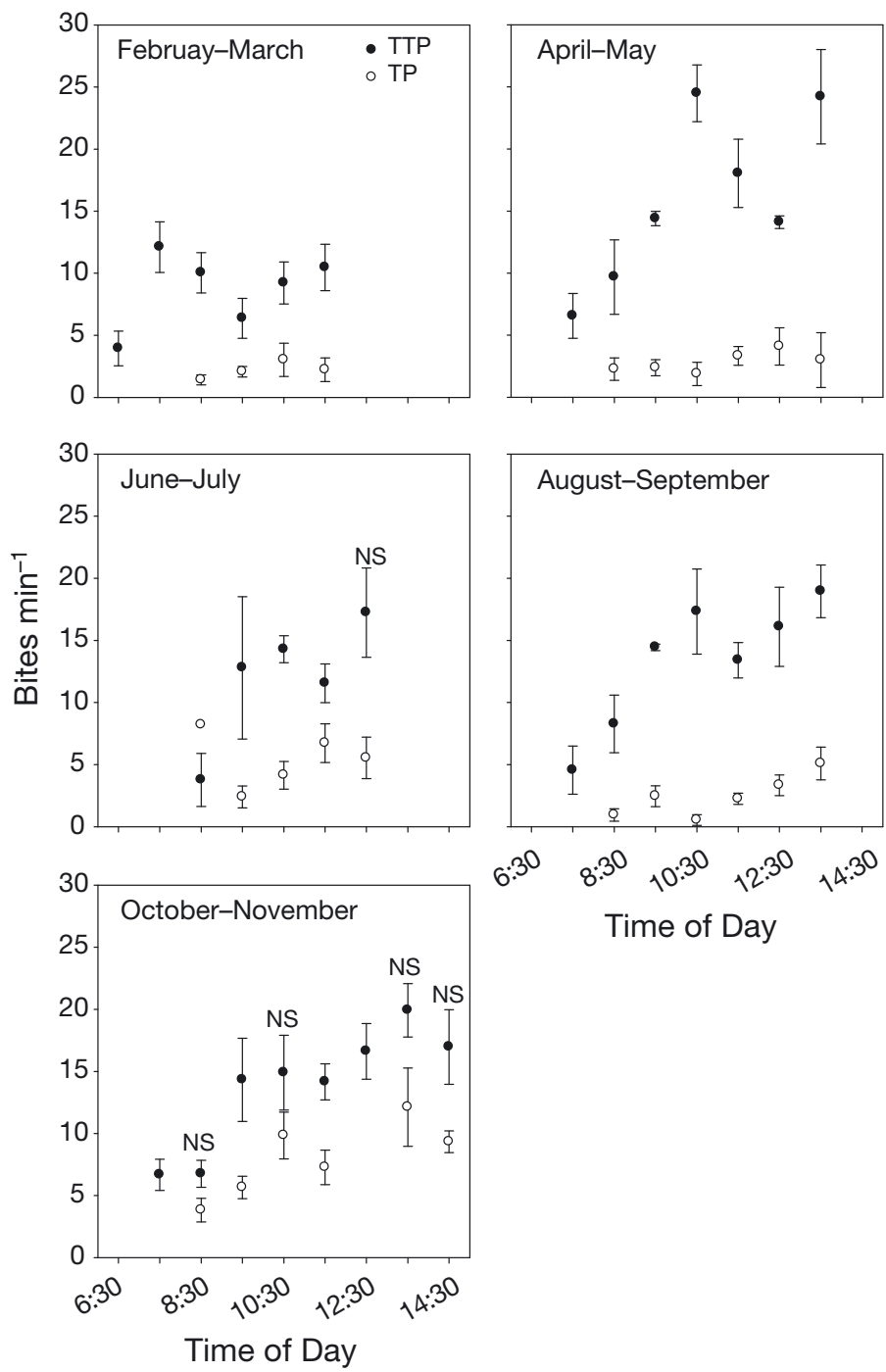

$6.3^{0} \quad 8.3^{0} \quad 10.3^{0} \quad 12.3^{0} \quad 14.3^{\circ}$

Time of Day significant (ANCOVA; IP: $F_{1,16}=2.532, \mathrm{p}=0.131$; TP: $\left.F_{1,10}=0.889, \mathrm{p}=0.368\right)$. The overall value of the yield per bite for each size class was therefore estimated by pooling data from both periods (February-March and October-November) (Table 2, Fig. 5).

\section{Total daily bites and daily intake rates}

Estimates of TDB for both size classes are shown in Fig. 4. During all periods, TDB of IP was significantly higher than that of TP (Z-test: $p<0.0005$ ), while TTP had a significantly lower TDB than TP in all periods (Z-test: $p<0.0128$ ) except during OctoberNovember (Z-test: $\mathrm{p}>0.127$ ). In IP, TDB tended to be higher in the warmer months, with the lowest number of bites recorded in the February-March and October-November periods. For both TP and TTP

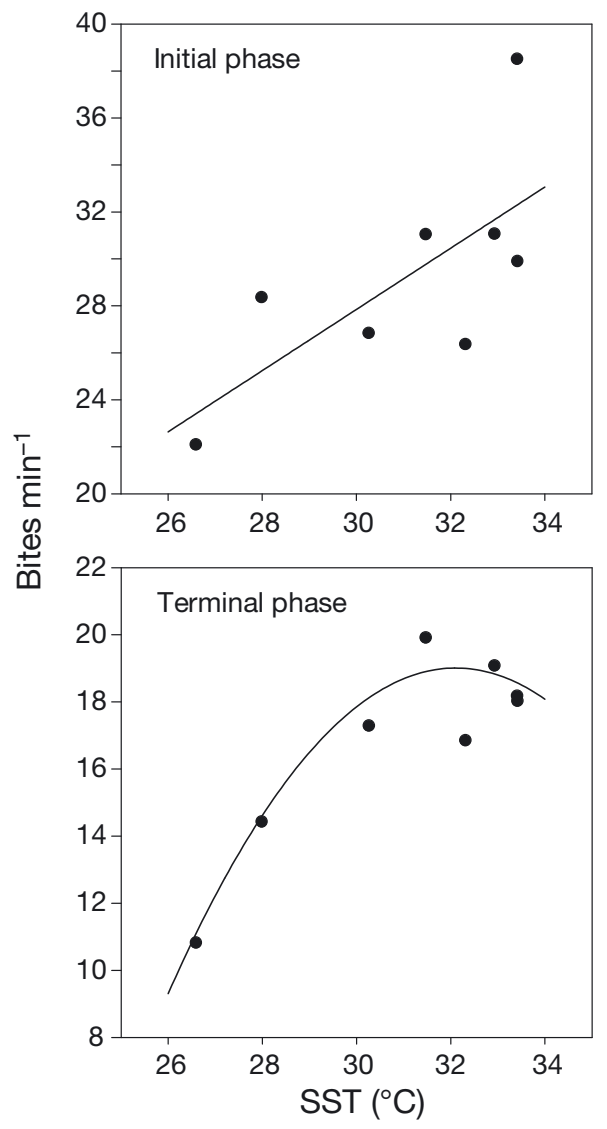

Fig. 3. Scarus ferrugineus. Relationships between monthly mean sea surface temperature (SST) and mean bite rate during the peak feeding time (12:00 to 18:00 h) for initial phase ( 20 to $25 \mathrm{~cm}$ fork length) and terminal phase (30 to $35 \mathrm{~cm}$ fork length) fish. Note the difference in scale of $y$-axes
Fig. 2. Scarus ferrugineus. Bite rates (means $\pm \mathrm{SE}$ ) of large ( 30 to $35 \mathrm{~cm}$ ) territorial terminal phase males (TTP) and nonterritorial terminal phase males (TP) for periods when TTP keep a temporary spawning territory in the deep fore-reef and TP forage at shallow reef zones. NS: no significant difference in bite rate between TTP and TP within a time period

is weak and bite rates remain low throughout the day. This pattern is most pronounced in the larger size class.

\section{Yield per bite}

Gut DM increased linearly with the cumulative number of bites in both IP and TP (Fig. 5). Yield per bite did not differ between the 2 periods (interaction term in Table 1) for both life phases. Within each life phase, the effect of fork length was not 


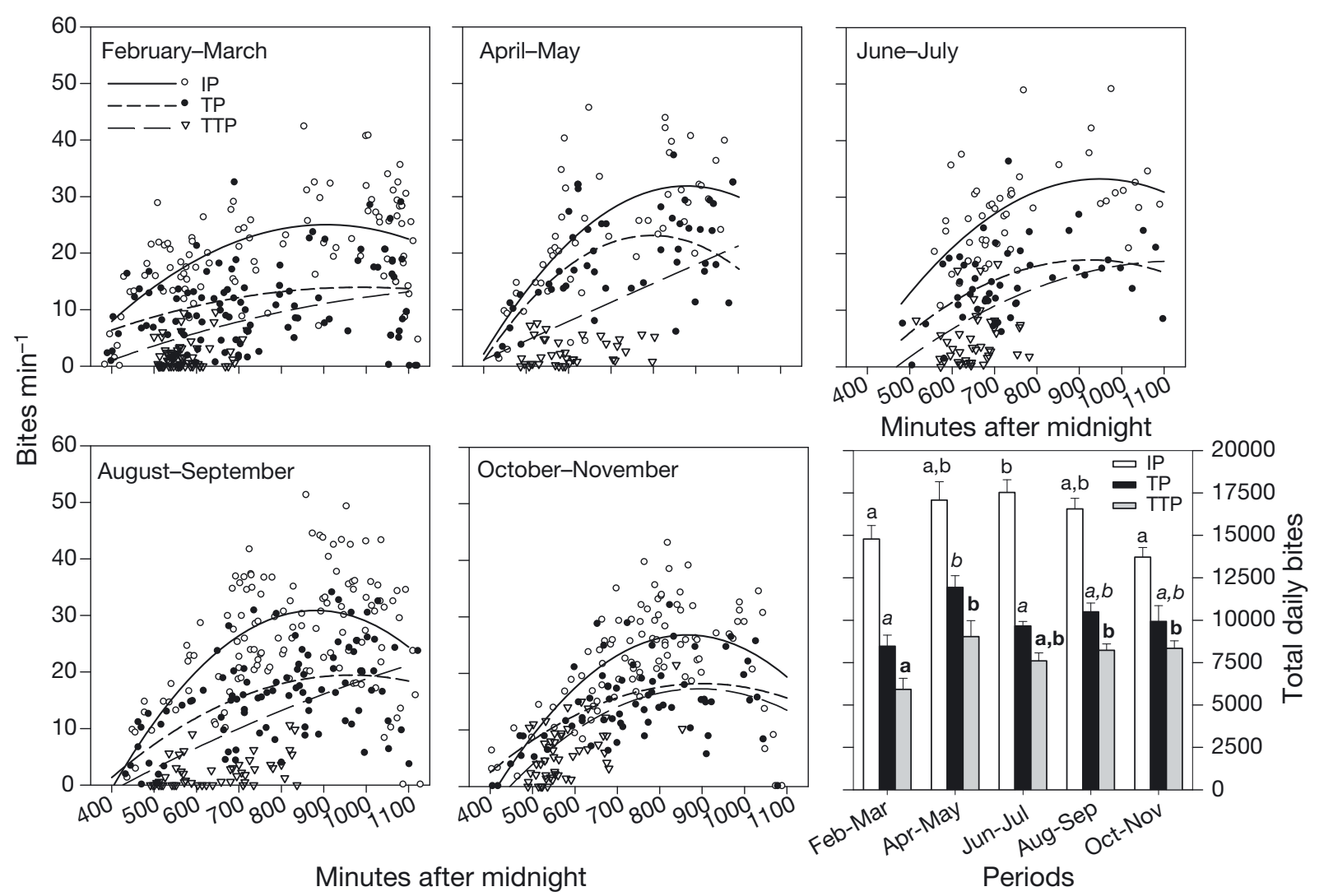

Fig. 4. Scarus ferrugineus. Diurnal pattern in bite rates of initial phase (IP), terminal phase (TP) and territorial terminal phase males (TTP) in different periods of the year. Lower right panel: mean total daily bites $( \pm \mathrm{SE})$ taken by IP, TP and TTP. For each life phase, significant differences between periods are indicated with different letters

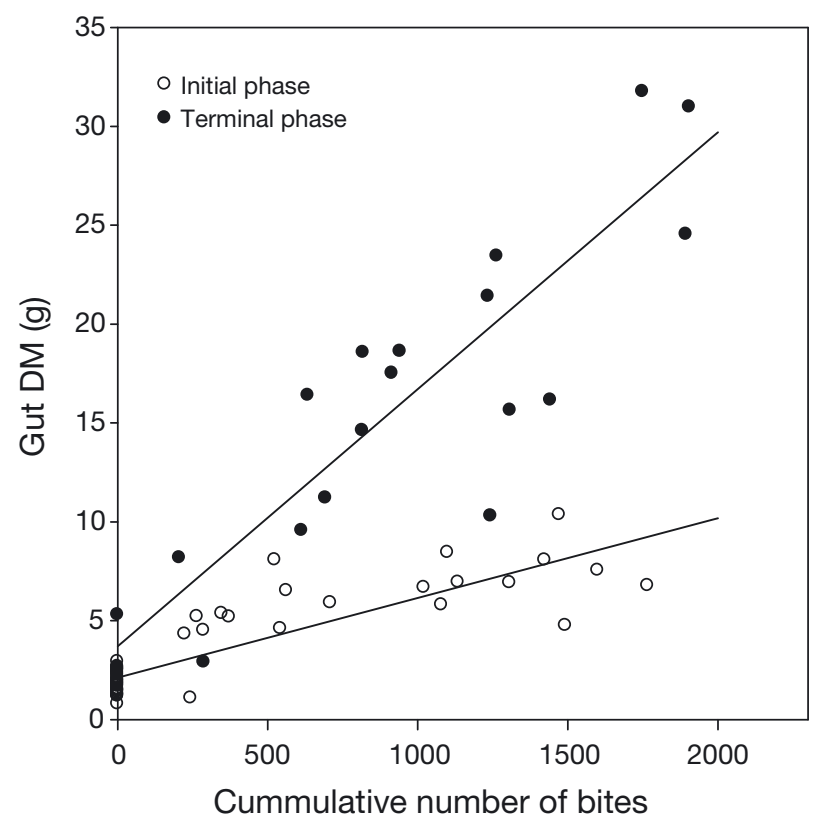

Fig. 5. Scarus ferrugineus. Increment in gut dry mass (DM) as a function of cumulative number of bites for initial phase (20 to $25 \mathrm{~cm}$ fork length) and terminal phase (30 to $35 \mathrm{~cm}$ fork length) fish, TDB peaked during the April-May period. Estimated daily intake (DM and AFDM) by IP, TP and TTP during different times of the year is presented in Table 3 .

\section{Defecation rate}

The daily pattern in defecation rate was investigated during the February-March and OctoberNovember periods. In both IP and TP, defecation commenced abruptly between 09:00 and 10:00 h during the cold period (Fig. 6). However, during the October-November period, defecation in the IP started earlier, between 08:00 and 09:00 h. Once initiated, defecation remained high throughout the day at a rate of 0.12 to 0.29 defecations $\mathrm{min}^{-1}$ for the IP and 0.09 to 0.18 defecations $\mathrm{min}^{-1}$ for the TP (Fig. 6). The mean defecation rate showed a seasonal pattern similar to the bite rate. The defecation rate was generally higher during the warmer periods of the year, when bite rates were also higher (Fig. 6). For the 20 to $25 \mathrm{~cm}$ size class, the difference in defecation rates between periods is 
Table 1. Scarus ferrugineus. Generalised linear model results of the relationship between gut dry mass ( $g$ ) and cumulative number of bites at 2 different periods of the year (February-March, October-November). IP: initial phase; TP: terminal phase. Significant effects are shown in bold

\begin{tabular}{|c|c|c|c|c|c|c|c|c|}
\hline \multirow[t]{2}{*}{ Source } & \multicolumn{4}{|c|}{$20-25 \mathrm{~cm} \mathrm{IP}-$} & \multicolumn{4}{|c|}{$-30-35 \mathrm{~cm} \mathrm{TP}$} \\
\hline & SS & df & $F$ & $\mathrm{p}$ & SS & df & $F$ & $\mathrm{p}$ \\
\hline Bites & 191.580 & 1,38 & 162.633 & $<0.001$ & 414.984 & 1,16 & 32.174 & $<0.001$ \\
\hline Period & 2.010 & 1 & 1.706 & 0.200 & 5.212 & 1 & 0.404 & 0.537 \\
\hline Period $\times$ Bites & 0.044 & 1 & 0.037 & 0.848 & 32.754 & 1 & 2.539 & 0.137 \\
\hline
\end{tabular}

through the morning, reaching peak values in the afternoon. This widespread phenomenon is thought to be driven by the higher productivity and nutritional quality of turf algae later in the day (Polunin \& Klumpp 1989, Zoufal \& Taborsky 1991). In $S$. ferrugineus, the weakest daily pattern was observed during the cool season (February-March), when primary production in turf algae is at its lowest (Ateweberhan et al. 2006). The difference in productivity Table 2. Scarus ferrugineus. Parameter estimates $( \pm \mathrm{SE})$ of the linear regression of gut mass with the cumulative number of bites $(\mathrm{DM}$ [or AFDM] $=a \times$ Bites $+b)$. AFDM: ash-free dry mass; DM: dry mass; IP: initial phase; TP: terminal phase

\begin{tabular}{|lccccc|}
\hline \multicolumn{1}{|c}{$a$} & $b$ & $\mathrm{R}^{2}$ & $\mathrm{p}$ & $\mathrm{n}$ \\
\hline $\mathbf{2 0 - 2 5}$ cm IP & & & & & \\
DM & $0.0049(0.00037)$ & $2.16(0.21)$ & 0.82 & 0 & 39 \\
AFDM & $0.00054(0.00019)$ & $1.75(0.18)$ & 0.3 & 0.01 & 21 \\
$\mathbf{3 0 - 3 5} \mathbf{~ c m ~ T P ~}$ & & & & \\
DM & $0.013(0.0015)$ & $3.71(1.66)$ & 0.77 & 0 & 19 \\
AFDM & $0.0015(0.00069)$ & $3.07(0.88)$ & 0.27 & 0.057 & 14 \\
& & & & & \\
\hline
\end{tabular}

significant (ANOVA: $F_{3,212}=9.738, \mathrm{p}<0.001$ ), but the difference for the 30 to $35 \mathrm{~cm}$ size class is not (ANOVA: $F_{3,137}=2.097, \mathrm{p}=0.103$ ).

\section{DISCUSSION}

\section{Bite rates, total daily bites and intake rates}

Daily rhythm in bite rate in Scarus ferrugineus fits well with patterns reported for other herbivorous reef fishes including blennies, damselfishes, surgeonfishes and parrotfishes (Zemke-White et al. 2002). In all these groups, bite rate tends to rise between morning and afternoon is expected to be more pronounced during the seasons of high solar radiation and high primary productivity (Polunin \& Klumpp 1989, Ateweberhan et al. 2005a), leading to the observed stronger daily pattern of higher afternoon bite rates in the warm season compared to the cool season.

Compared to other similar-sized scarids (Bellwood 1995, Ong \& Holland 2010), Scarus ferrugineus generally feeds at a higher rate and takes more bites per day, particularly during spring and summer. Defecation rates are the highest during this period, indicating that the gut turnover rates and hence digestive processes are faster. This may be due to the higher SSTs at our study site $\left(27\right.$ to $\left.34^{\circ} \mathrm{C}\right)$ compared to the other locations $\left(24\right.$ to $28^{\circ} \mathrm{C}$ for the Great Barrier Reef and $27^{\circ} \mathrm{C}$ for Hawaii). In spite of higher bite rates, the estimated daily ingestion of grazed AFDM lies within the range of values reported for other parrotfishes (Bruggemann et al. 1994b,c, Ferreira et al. 1998).

Seasonally varying bite rates in coral reef grazers are commonly reported (Polunin \& Klumpp 1992, Ferreira et al. 1998). Parameters causing this variation in feeding rate are temperature, biomass, nutritional quality and productivity of turfs (Horn \& Gibson 1990, Bowen et al. 1995, Clements et al. 2009). All these parameters vary seasonally at our study

Table 3. Scarus ferrugineus. Mean daily intake of epilithic algae community $( \pm \mathrm{SE})$ by initial phase (IP), terminal phase (TP) and territorial terminal phase (TTP) individuals. AFDM: ash-free dry mass; DM: dry mass

\begin{tabular}{|c|c|c|c|c|c|c|}
\hline \multirow[t]{2}{*}{ Period } & \multicolumn{2}{|c|}{$20-25 \mathrm{~cm}$ IP } & \multicolumn{2}{|c|}{$30-35 \mathrm{~cm}$ TP } & \multicolumn{2}{|c|}{$30-35 \mathrm{~cm}$ TTP } \\
\hline & $\left(g \mathrm{DM} \mathrm{d} \mathrm{d}^{-1}\right)$ & $\left(\mathrm{g} \mathrm{AFDM} \mathrm{d}^{-1}\right)$ & $\left(\mathrm{g} \mathrm{DM} \mathrm{d}^{-1}\right)$ & $\left(g_{A F D M ~ d}{ }^{-1}\right)$ & $\left(\mathrm{g} D M d^{-1}\right)$ & $\left(\mathrm{g} \mathrm{AFDM} \mathrm{d}^{-1}\right)$ \\
\hline Feb-Mar & $71.96(6.16)$ & $8.04(2.84)$ & $107.40(15.51)$ & 12.39 (5.99) & 75.15 (12.39) & $8.68(4.26)$ \\
\hline Apr-May & $83.14(8.02)$ & $9.28(3.31)$ & 151.39 (20.39) & $17.48(8.39)$ & $114.58(18.40)$ & $13.23(6.48)$ \\
\hline Jun-Jul & $85.75(7.87)$ & $9.57(3.40)$ & $122.52(15.67)$ & $14.15(6.75)$ & $95.52(13.43)$ & $11.03(5.32)$ \\
\hline Aug-Sep & $80.71(7.00)$ & $9.02(3.19)$ & $133.56(17.72)$ & $15.41(7.39)$ & $104.21(13.63)$ & $12.03(5.76)$ \\
\hline Oct-Nov & $66.82(5.81)$ & $7.46(2.64)$ & $125.94(19.45)$ & $14.53(7.08)$ & $105.83(14.40)$ & $12.21(5.86)$ \\
\hline
\end{tabular}



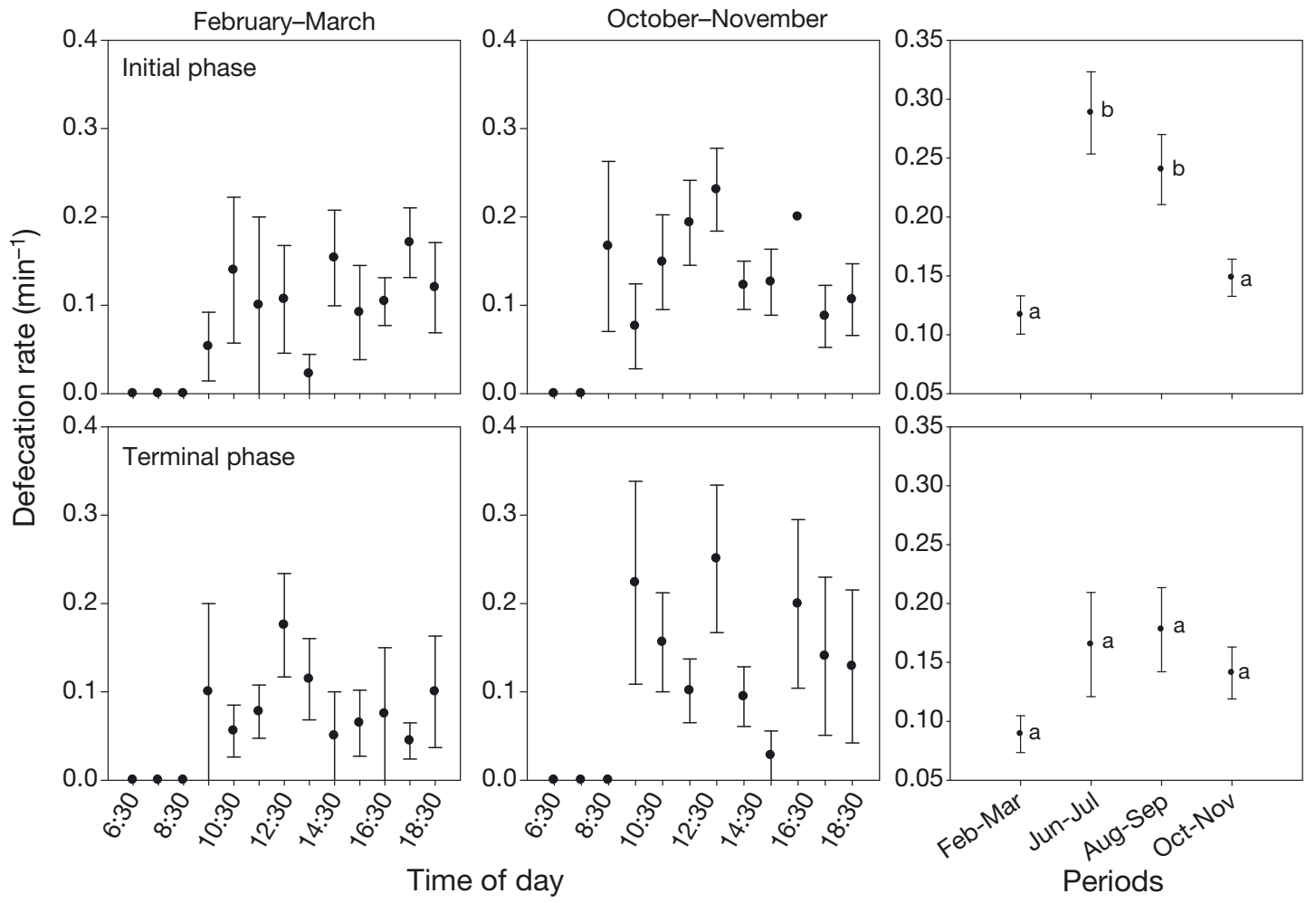

Fig. 6. Scarus ferrugineus. Daily pattern of mean defecation rates $( \pm$ SE) in initial phase and terminal phase during February-March and October-November periods. Right panels: mean defecation rates $( \pm$ SE) in different periods. Significant differences between periods are indicated with different letters

site. EAM biomass is lowest in the warmer seasons (Ateweberhan et al. 2006, see Fig. S2a in the Supplement), while its nutritional quality expressed as percentage organic matter of DM is highest during this period (see Fig. S2b,c in the Supplement). Highbiomass turfs are associated with high sediment loads and hence represent poorer quality food (Purcell 2000, Purcell \& Bellwood 2001). Also, productivity is expected to be higher in the warmer seasons since both photosynthetically active radiation and temperature-the main parameters that affect primary productivity - are highest during this period (Ateweberhan et al. 2005a). It is therefore plausible that the higher bite rates in the warmer parts of the year for Scarus ferrugineus could be due to increased nutritional quality, higher productivity, higher temperatures or a combination of these. More experimental work is needed to separate the relative roles of these factors.

We did not analyse the dietary components of the material ingested by Scarus ferrugineus. However, behavioural observations show that the species mainly targets the EAM (Afeworki et al. 2011). Detritus is an integral part of the EAM, and its nutritional quality is comparable to or better than that of the algae (Crossman et al. 2001, Wilson et al. 2003). When parrotfishes take bites, they include all the components of the EAM, i.e. the detritus, the epilithic algae and the substrate-bound endolithic algae (Bruggemann et al. 1994b,c). Gut content of S. ferrugineus and other parrotfishes (Choat et al. 2002) typically is a triturated mass of sediment, algal fragments and detritus, reflecting its EAM source. Indeed, dietary analyses have confirmed that parrotfishes of the genera Scarus and Chlorurus ingest large amounts of detritus (Choat et al. 2002, 2004).

Varying levels of food intake are likely to influence life history decisions such as investment in reproduction and growth (Jones 1986, Clifton 1995). In Scarus ferrugineus, the low intake rate during the cooler parts of the year coincides with near-zero growth rates, low body condition and declining liver mass indices (Y. Afeworki unpubl. data). Low daily bite rates during the cool season are possibly due to a combination of low temperature (see below), low abundance of the preferred food item (Afeworki et al. 2011) and higher sediment load of turfs during this season (see Fig. S2c in the Supplement). As a result, the cool season represents a period of lower energy and nutrient intake for this population of $S$. ferrug- 
ineus that may limit growth and reproduction. In contrast, the temporal concordance of the high nutritional quality of EAM, high intake rates and high processing rates during the warm season strongly suggests that $S$. ferrugineus is nutritionally and energetically better off in the warmer parts of year.

\section{Size and bite rate}

Bite rate follows a quadratic function with size, and the peak values occur at intermediate sizes (Bruggemann et al. 1994b, this study). By controlling for the role of territoriality (see Table S1 in the Supplement), our results clearly demonstrated that fish size, not life phase as such, determines bite rate. Size also affects the area scraped per bite (scraping capacity), being higher in larger than in smaller individuals (Bruggemann et al. 1996, Bonaldo \& Bellwood 2008, Afeworki et al. 2011). Changes in the size structure of parrotfish populations, e.g. as a result of overfishing, will therefore affect the capacity of parrotfish to remove algae from coral substrates and the role of this functional group in maintaining reef resilience (Lokrantz et al. 2008, Jayewardene 2009).

Declining bite rate with size beyond the inflexion point $(>15 \mathrm{~cm})$ is compensated by the larger yield per bite, leading to larger daily intake for these size classes (this study). For this part of the curve, the lower bite rates may be a direct result of the mechanics associated with bigger bites, analogous to the difference in bite rate between scrapers (which generally have high bite rates) and excavators (which take fewer but more forceful bites) (Bellwood \& Choat 1990, Bruggemann et al. 1994c). Juveniles, however, have a smaller yield per bite (Bruggemann et al. 1994b) and lower bite rate, which may lead to lower daily intake in this group unless they target food items of higher nutritional quality, a phenomenon that is usually associated with lower feeding rates (Bruggemann et al. 1994b, Bowen et al. 1995, Choat et al. 2004). It is possible that juveniles target nutritionally better components of the epilithic algal community such as the meiofauna and/or detritus (Bellwood 1988, Bruggemann et al. 1994b, Chen 2002).

\section{Territorial behaviour and bite rate}

During spawning, territorial males spend a large part of their time on non-foraging activities, leading to a significant reduction in bite rates (Bruggemann et al. 1994b, van Rooij 1996, Bonaldo et al. 2006). In
Scarus ferrugineus, spawning-related losses in intake amount to $\sim 23 \%$ of the daily intake. This loss is exacerbated by the higher energy expenditure associated with territoriality. Indeed, spawning behaviour often involves increased swimming activity associated with agnostic encounters and territory defence (van Rooij 1996, Taborsky \& Grantner 1998), which in turn affect growth and body condition of TTP (van Rooij et al. 1995a,b). We have observed similar effects in $S$. ferrugineus where TP have higher mortality rates and shorter life spans than IP (Y. Afeworki unpubl. data). Energetic constraints associated with territoriality may partly explain this reduced survivorship in TP.

Another way in which spawning can interfere with food intake is through the spatial disparity between spawning and foraging zones (Robertson 1991, Kuwamura et al. 2009). Scarids, and reef grazers in general, typically forage in the highly productive shallow reef zones (Hay 1981, Fox \& Bellwood 2007, Brokovich et al. 2010). Spawning sites are normally located at deeper reef sites (van Rooij 1996). The importance of shallow reef areas for foraging parrotfishes is reflected in the tendency of many species to commute between shallow foraging and deeper spawning locations (Johannes 1978, Kuwamura et al. 2009). A similar condition exists in Scarus ferrugineus, where TTP migrate to the spawning sites located at the deep fore-reef. At the end of each spawning episode, the TTP swim back to the reef crest, where most of the foraging activity occurs.

\section{Temperature and bite rate}

The relationship between feeding rate and temperature in fish follows a dome-shaped curve, where high temperatures cause a decline in feeding rate (Jobling 1994, Koskela et al. 1997). This is associated with the decline in the aerobic scope of marine organisms at high temperatures due to the incapacity of the circulatory and ventilatory systems to cope with the high oxygen demand (Pörtner \& Knust 2007, Nilsson et al. 2009). This effect is more pronounced in large than in small individuals (Hernandez et al. 2002, Peck et al. 2009, Morita et al. 2010). Consequently, fish populations will be composed of smaller individuals in warmer conditions (Daufresne et al. 2009). Our results suggest that at our study site, the larger size class of Scarus ferrugineus is close to its upper critical temperature during the summer months. This is corroborated by previous studies at our site that pointed out a possible temperature- 
mediated suppression of grazing during summer in the hot shallow zones, leading to a shift in grazing intensity to the deeper and cooler reef zones (Ateweberhan et al. 2006, Afeworki et al. 2013).

Summer SSTs at our study site at $2 \mathrm{~m}$ depth ranged from 32 to $34^{\circ} \mathrm{C}$, while on the reef flats they often exceeded $36^{\circ} \mathrm{C}$ (Ateweberhan et al. 2005a, 2006). These SSTs are equal to or higher than those reported as critical temperatures for some coral reef fishes (Mora \& Ospina 2001, Nilsson et al. 2009). Our results suggest that such high temperatures are likely to negatively affect large parrotfishes first, which over time may lead to reductions in size structure of the population.

The link between temperature and body size likely represents a critical mechanism by which global warming could alter the grazing function on coral reefs. Body size is a critical determinant of the ecological role of parrotfishes, such as grazing impact and bioeroding capacity, both of which increase exponentially with size (Bruggemann et al. 1996, Bonaldo \& Bellwood 2008, Lokrantz et al. 2008). It has been noted that overfishing, by extirpating large parrotfishes, greatly impairs the resilience of coral reefs (Bonaldo \& Bellwood 2008, Lokrantz et al. 2009, Bellwood et al. 2012). By protecting large herbivores from overfishing, grazing and hence the potential for recovery of corals after disturbance are enhanced in marine protected areas (Mumby et al. 2006, 2007). Unlike overfishing, global warming could affect parrotfish communities on large spatial scales. Many reefs can be expected to experience changes in the size structure of fish populations, leading to communities that are dominated by smaller individuals and species. This will be particularly severe in locations subject to rapid warming (Sherman et al. 2009, Raitsos et al. 2011) or those that already experience extreme summer temperatures, such as the southern Red Sea and the Persian Gulf (Kleypas et al. 1999). If global warming indeed leads to reefs that are dominated by smaller individuals, the resulting reduction in grazing impact by parrotfishes may compromise their role in maintaining the resilience capacity of coral reefs.

Acknowledgements. We gratefully acknowledge the financial support of the Netherlands Foundation for the Advancement of Tropical Research (WOTRO grant W84-589), the Nicolaas Mulerius Foundation, the Eric Bleumink Foundation and S. Daan (Niko Tinbergen distinguished honorary chair in Behavioural Biology) of the University of Groningen. We thank Y. Hiabu, H. Iyob, S. Mohammed, F. Yohannes and Y Gebremedhin for their assistance during field and laboratory work. We thank 4 anonymous reviewers whose comments greatly improved this manuscript. Y.A. thanks the staff of the College of Marine Sciences and Technology, Massawa; Department of Ocean Ecosystems, University of Groningen; and the Research Unit of the Ministry of Fisheries, Eritrea, for working facilities.

\section{LITERATURE CITED}

Afeworki Y, Bruggemann JH, Videler JJ (2011) Limited flexibility in resource use in a coral reef grazer foraging on seasonally changing algal communities. Coral Reefs 30: 109-122

Afeworki Y, Videler JJ, Bruggemann JH (2013) Seasonally changing habitat use patterns among roving herbivorous fishes in the southern Red Sea: the role of temperature and algal community structure. Coral Reefs 32: 475-485

Ateweberhan M, Bruggemann JH, Breeman AM (2005a) Seasonal dynamics of Sargassum ilicifolium (Phaeophyta) on a shallow reef flat in the southern Red Sea (Eritrea). Mar Ecol Prog Ser 292:159-171

Ateweberhan M, Bruggemann JH, Breeman AM (2005b) Seasonal patterns of biomass, growth and reproduction in Dictyota cervicornis and Stoechospermum polypodioides (Dictyotales, Phaeophyta) on a shallow reef flat in the southern Red Sea (Eritrea). Bot Mar 48:8-17

Ateweberhan M, Bruggemann JH, Breeman AM (2006) Effects of extreme seasonality on community structure and functional group dynamics of coral reef algae in the southern Red Sea (Eritrea). Coral Reefs 25:391-406

Barneche DR, Floeter SR, Ceccarelli DM, Frensel DMB, Dinslaken DF, Mario HFS, Ferreira CEL (2009) Feeding macroecology of territorial damselfishes (Perciformes: Pomacentridae). Mar Biol 156:289-299

> Bellwood DR (1988) Ontogenetic changes in the diet of early post-settlement Scarus species (Pisces, Scaridae). J Fish Biol 33:213-219

> Bellwood DR (1995) Direct estimate of bioerosion by two parrotfish species, Chlorurus gibbus and C. sordidus, on the Great Barrier Reef, Australia. Mar Biol 121:419-429

- Bellwood DR, Choat JH (1990) A functional analysis of grazing in parrotfishes (Family Scaridae): the ecological implications. Environ Biol Fishes 28:189-214

Bellwood DR, Hoey AS, Hughes TP (2012) Human activity selectively impacts the ecosystem roles of parrotfishes on coral reefs. Proc R Soc Lond B Biol Sci 279:1621-1629

Benjamini Y, Hochberg Y (1995) Controlling the false discovery rate: a practical and powerful approach to multiple testing. J R Statist Soc B 57:289-300

Bonaldo RM, Bellwood DR (2008) Size-dependent variation in the functional role of the parrotfish Scarus rivulatus on the Great Barrier Reef, Australia. Mar Ecol Prog Ser 360: 237-244

Bonaldo RM, Krajewski JP, Sazima C, Sazima I (2006) Foraging activity and resource use by three parrotfish species at Fernando de Noronha Archipelago, tropical West Atlantic. Mar Biol 149:423-433

> Bowen SH, Lutz EV, Ahlgren MO (1995) Dietary protein and energy as determinants of food quality: trophic strategies compared. Ecology 76:899-907

> Brokovich E, Ayalon I, Einbinder S, Segev N and others (2010) Grazing pressure on coral reefs decreases across a wide depth gradient in the Gulf of Aqaba, Red Sea. Mar Ecol Prog Ser 399:69-80

Bruggemann JH, van Oppen MJH, Breeman AM (1994a) 
Foraging by the stoplight parrotfish Sparisoma viride. I. Food selection in different, socially determined habitats. Mar Ecol Prog Ser 106:41-55

> Bruggemann JH, Begeman J, Bosma EM, Verburg P, Breeman AM (1994b) Foraging by the stoplight parrotfish Sparisoma viride. II. Intake and assimilation of food, protein and energy. Mar Ecol Prog Ser 106:57-71

> Bruggemann JH, Kuyper MWM, Breeman AM (1994c) Comparative analysis of foraging and habitat use by the sympatric Caribbean parrotfish Scarus vetula and Sparisoma viride (Scaridae). Mar Ecol Prog Ser 112:51-66

> Bruggemann JH, van Kessel AM, van Rooij JM, Breeman AM (1996) Bioerosion and sediment ingestion by the Caribbean parrotfish Scarus vetula and Sparisoma viride: implications of fish size, feeding mode and habitat use. Mar Ecol Prog Ser 134:59-71

> Carpenter RC (1985) Relationships between primary production and irradiance in coral reef algal communities. Limnol Oceanogr 30:784-793

> Carpenter RC (1988) Mass mortality of a Caribbean sea urchin: immediate effects on community metabolism and other herbivores. Proc Natl Acad Sci USA 85:511-514

Chen LS (2002) Post-settlement diet shift of Chlorurus sordidus and Scarus schlegeli (Pisces: Scaridae). Zool Stud 41:47-58

Choat JH, Robertson DR (2002) Age-based studies. In: Sale PF (ed) Coral reef fishes: dynamics and diversity in a complex ecosystem. Academic Press, San Diego, CA, p 57-80

> Choat JH, Clements KD, Robbins W (2002) The trophic status of herbivorous fishes on coral reefs. I. Dietary analyses. Mar Biol 140:613-623

> Choat JH, Robbins WD, Clements KD (2004) The trophic status of herbivorous fishes on coral reefs. II. Food processing modes and trophodynamics. Mar Biol 145: 445-454

Clements KD, Raubenheimer D, Choat JH (2009) Nutritional ecology of marine herbivorous fishes: ten years on. Funct Ecol 23:79-92

> Clifton KE (1995) Asynchronous food availability on neighboring Caribbean coral reefs determines seasonal patterns of growth and reproduction for the herbivorous parrotfish Scarus iserti. Mar Ecol Prog Ser 116:39-46

Crossman DJ, Choat JH, Clements KD, Hardy T, McConochie J (2001) Detritus as food for grazing fishes on coral reefs. Limnol Oceanogr 46:1596-1605

> Daufresne M, Lengfellner K, Sommer U (2009) Global warming benefits the small in aquatic ecosystems. Proc Natl Acad Sci USA 106:12788-12793

Englund G, Ohlund G, Hein CL, Diehl S (2011) Temperature dependence of the functional response. Ecol Lett 14: 914-921

> Feary DA, Burt JA, Bauman AG, Usseglio P, Sale PF, Cavalcante GH (2010) Fish communities on the world's warmest reefs: What can they tell us about the effects of climate change in the future? J Fish Biol 77:1931-1947

Ferreira CEL, Peret AC, Coutinho R (1998) Seasonal grazing rates and food processing by tropical herbivorous fishes. J Fish Biol 53:222-235

> Floeter SR, Behrens MD, Ferreira CEL, Paddack MJ, Horn $\mathrm{MH}$ (2005) Geographical gradients of marine herbivorous fishes: patterns and processes. Mar Biol 147: 1435-1447

Fox RJ, Bellwood DR (2007) Quantifying herbivory across a coral reef depth gradient. Mar Ecol Prog Ser 339:49-59
Hatcher BG (1982) The interaction between grazing organisms and the epilithic algal community of a coral reef: a quantitative assessment. Proc 4th Int Coral Reef Symp 2: 515-524

- Hay ME (1981) Spatial patterns of grazing intensity on a Caribbean barrier reef: herbivory and algal distribution. Aquat Bot 11:97-109

Hernandez CE, Neill PE, Pulgar JM, Ojeda FP, Bozinovic F (2002) Water temperature fluctuations and territoriality in the intertidal zone: two possible explanations for the elevational distribution of body size in Graus nigra. J Fish Biol 61:472-488

Horn MH (1989) Biology of marine herbivorous fishes. Oceanogr Mar Biol Annu Rev 27:167-272

> Horn MH, Gibson RN (1990) Effects of temperature on the food processing of three species of seaweed-eating fishes from European coastal waters. J Fish Biol 37:237-247

> Jayewardene D (2009) A factorial experiment quantifying the influence of parrotfish density and size on algal reduction on Hawaiian coral reefs. J Exp Mar Biol Ecol 375:64-69

Jobling M (1994) Fish bioenergetics. Chapman \& Hall, London

Johannes RE (1978) Reproductive strategies of coastal marine fishes in the tropics. Environ Biol Fishes 3:65-84

Jones GP (1986) Food availability affects growth in a coral reef fish. Oecologia 70:136-139

> Kingsford M (1992) Spatial and temporal variation in predation on reef fishes by coral trout (Plectropomus leopardus, Serranidae). Coral Reefs 11:193-198

Kleypas JA, McManus JW, Menez LAB (1999) Environmental limits to coral reef development: Where do we draw the line? Am Zool 39:146-159

Klumpp DW, Mckinnon AD (1989) Temporal and spatial patterns in primary production of a coral-reef epilithic algal community. J Exp Mar Biol Ecol 131:1-22

Klumpp DW, Polunin NVC (1990) Algal production, grazers and habitat partitioning on a coral reef: positive correlation between grazing rate and food availability. In: Barnes M, Gibson RN (eds) Trophic relationships in the marine environment. Aberdeen University Press, Aberdeen, p 372-388

> Koskela J, Pirhonen J, Jobling M (1997) Feed intake, growth rate and body composition of juvenile Baltic salmon exposed to different constant temperatures. Aquacult Int 5:351-360

Kuwamura T, Sagawa T, Suzuki S (2009) Interspecific variation in spawning time and male mating tactics of the parrotfishes on a fringing coral reef at Iriomote Island, Okinawa. Ichthyol Res 56:354-362

> Lokrantz J, Nystrom M, Thyresson M, Johansson C (2008) The non-linear relationship between body size and function in parrotfishes. Coral Reefs 27:967-974

Lokrantz J, Nystrom M, Norstrom AV, Folke C, Cinner JE (2009) Impacts of artisanal fishing on key functional groups and the potential vulnerability of coral reefs. Environ Conserv 36:327-337

> Montgomery WL (1980) Comparative feeding ecology of two herbivorous damselfishes (Pomacentridae: Teleostei) from the Gulf of California, Mexico. J Exp Mar Biol Ecol 47:9-24

Mora C, Ospina AF (2001) Tolerance to high temperatures and potential impact of sea warming on reef fishes of Gorgona Island (tropical eastern Pacific). Mar Biol 139: 765-769 
Morita K, Fukuwaka M, Tanimata N, Yamamura O (2010) Size-dependent thermal preferences in a pelagic fish. Oikos 119:1265-1272

Mumby PJ, Dahlgren CP, Harborne AR, Kappel CV and others (2006) Fishing, trophic cascades, and the process of grazing on coral reefs. Science 311:98-101

Mumby PJ, Harborne AR, Williams J, Kappel CV and others (2007) Trophic cascade facilitates coral recruitment in a marine reserve. Proc Natl Acad Sci USA 104:8362-8367

> Munday PL, Jones GP, Pratchett MS, Williams AJ (2008) Climate change and the future for coral reef fishes. Fish Fish 9:261-285

Nilsson GE, Crawley N, Lunde IG, Munday PL (2009) Elevated temperature reduces the respiratory scope of coral reef fishes. Glob Change Biol 15:1405-1412

Ong L, Holland KN (2010) Bioerosion of coral reefs by two Hawaiian parrotfishes: species, size differences and fishery implications. Mar Biol 157:1313-1323

Peck LS, Clark MS, Morley SA, Massey A, Rossetti H (2009) Animal temperature limits and ecological relevance: effects of size, activity and rates of change. Funct Ecol 23: 248-256

Polunin NVC (1988) Efficient uptake of algal production by a single resident herbivorous fish on the reef. J Exp Mar Biol Ecol 123:61-76

Polunin NVC, Klumpp DW (1989) Ecological correlates of foraging periodicity in herbivorous reef fishes of the Coral Sea. J Exp Mar Biol Ecol 126:1-20

Polunin NVC, Klumpp DW (1992) Algal food supply and grazer demand in a very productive coral-reef zone. J Exp Mar Biol Ecol 164:1-15

Pörtner HO, Knust R (2007) Climate change affects marine fishes through the oxygen limitation of thermal tolerance. Science 315:95-97

Purcell SW (2000) Association of epilithic algae with sediment distribution on a windward reef in the northern Great Barrier Reef, Australia. Bull Mar Sci 66:199-214

> Purcell SW, Bellwood DR (2001) Spatial patterns of epilithic algal and detrital resources on a windward coral reef. Coral Reefs 20:117-125

Raitsos DE, Hoteit I, Prihartato PK, Chronis T, Triantafyllou G, Abualnaja Y (2011) Abrupt warming of the Red Sea. Geophys Res Lett 38:L14601, doi:10.1029/2011GL 047984

Robertson DR (1991) The role of adult biology in the timing of spawning of tropical reef fishes. In: Sale PF (ed) The ecology of fishes on coral reefs. Academic Press, San Diego, CA, p 356-386

Russ GR, St. John J (1988) Diets, growth rates and secondary

Editorial responsibility: Ivan Nagelkerken, Adelaide, South Australia, Australia production of herbivorous coral reef fishes. Proc 6th Int Coral Reef Symp 2:37-43

> Sherman K, Belkin IM, Friedland KD, O'Reilly J, Hyde K (2009) Accelerated warming and emergent trends in fisheries biomass yields of the world's large marine ecosystems. Ambio 38:215-224

Smith TB (2008) Temperature effects on herbivory for an Indo-Pacific parrotfish in Panama: implications for coral-algal competition. Coral Reefs 27:397-405

Sudekum A, Parrish J, Radtke R, Ralston S (1991) Life history and ecology of large jacks in undisturbed, shallow, oceanic communities. Fish Bull 89:493-513

Taborsky M, Grantner A (1998) Behavioural time-energy budgets of cooperatively breeding Neolamprologus pulcher (Pisces: Cichlidae). Anim Behav 56:1375-1382

Targett TE, Targett NM (1990) Energetics of food selection by the herbivorous parrotfish Sparisoma radians: roles of assimilation efficiency, gut evacuation rate, and algal secondary metabolites. Mar Ecol Prog Ser 66:13-21

van Rooij JM (1996) Behavioural energetics of the parrotfish Sparisoma viride: flexibility in a coral reef setting. $\mathrm{PhD}$ thesis, University of Groningen

van Rooij JM, Bruggemann JH, Videler JJ, Breeman AM (1995a) Ontogenic, social, spatial and seasonal variations in condition of the reef herbivore Sparisoma viride. Mar Biol 123:269-275

van Rooij JM, Bruggemann JH, Videler JJ, Breeman AM (1995b) Plastic growth of the herbivorous reef fish Sparisoma viride: field evidence for a trade-off between growth and reproduction. Mar Ecol Prog Ser 122:93-105

van Rooij JM, Videler JJ, Bruggemann JH (1998) High biomass and production but low energy transfer efficiency of Caribbean parrotfish: implications for trophic models of coral reefs. J Fish Biol 53:154-178

Williams ID, Polunin NVC (2001) Large-scale associations between macroalgal cover and grazer biomass on middepth reefs in the Caribbean. Coral Reefs 19:358-366

Wilson SK, Bellwood DR, Choat JH, Furnas MJ (2003) Detritus in the epilithic algal matrix and its use by coral reef fishes. Oceanogr Mar Biol Annu Rev 41:279-309

Zekeria ZA, Weertman S, Samuel B, Kale-ab T, Videler JJ (2006) Growth of Chaetodon larvatus (Chaetodontidae: Pisces) in the southern Red Sea. Mar Biol 148:1113-1122

Zemke-White WL, Choat JH, Clements KD (2002) A re-evaluation of the diel feeding hypothesis for marine herbivorous fishes. Mar Biol 141:571-579

Zoufal R, Taborsky M (1991) Fish foraging periodicity correlates with daily changes of diet quality. Mar Biol 108: 193-196

Submitted: March 23, 2012; Accepted: April 16, 2013 Proofs received from author(s): August 11, 2013 